\title{
INTERNATIONAL TRADE AND OPEN ACCESS RENEWABLE RESOURCES: THE SMALL OPEN ECONOMY CASE
}

James A. Brander M. Scott Taylor

Working Paper No. 5021

\author{
NATIONAL BUREAU OF ECONOMIC RESEARCH \\ 1050 Massachusetts Avenue \\ Cambridge, MA 02138 \\ February 1995
}

We thank Brian Copeland, Mukesh Eswaran, Gordon Munro and Tony Scott for very helpful comments and Carol McAusland for research assistance. We also thank seminar participants at U.B.C., the University of Washington, and at the 1994 Canadian Economic Association meetings in Calgary. Financial support from the Social Sciences Research Council of Canada and the U.B.C. Centre for International Business Studies is gratefully acknowledged. This paper is part of NBER's research program in International Trade and Investment. Any opinions expressed are those of the authors and not those of the National Bureau of Economic Research.

(C) 1995 by James A. Brander and M. Scott Taylor. All rights reserved. Short sections of text, not to exceed two paragraphs, may be quoted without explicit permission provided that full credit, including $\odot$ notice, is given to the source. 


\title{
INTERNATIONAL TRADE AND OPEN ACCESS RENEWABLE RESOURCES: THE SMALL OPEN ECONOMY CASE
}

\begin{abstract}
This paper develops a two-sector general equilibrium model of an economy with an open access renewable resource. We characterize the autarkic steady state, showing that autarky prices (and "comparative advantage") are determined by the ratio of intrinsic resource growth to labor. Under free trade, steady state trade and production patterns for a small open economy are determined by whether the resource good's world price exceeds its autarky price. Strikingly, if the small country exports the resource good while remaining diversified, then steady-state utility is lower than in autarky, and increases in the world price of exports are welfare-reducing.
\end{abstract}

James A. Brander

Faculty of Commerce

University of British Columbia

Vancouver, B.C. V6T 1 Z2

CANADA and NBER
M. Scott Taylor

Department of Economics

University of British Columbia

Vancouver, B.C. V6T 1Z1

CANADA 


\section{Introduction}

Concern over the sustainability of major renewable resource stocks has re-emerged as a significant international policy issue. For example, there have been widely publicized claims that forests in countries such as Brazil, Canada, and Indonesia are being harvested excessively rapidly. Other renewable resources, including fish and wildlife stocks, are also alleged to be under threat in many parts of the world.

Much of the concern over renewable resources arises from the "open access" problem. It has been well established (starting with the classic paper by Gordon (1954)) that resource overexploitation may occur when a common property resource is subject to open access ${ }^{1}$. More generally, we can observe that over-exploitation may occur if property rights over a resource stock are hard to define, difficult to enforce, or costly to administer. Such problems are alleged to be very important. For example, Loayaza (1992, p.xi), after noting that the fishing industry provides direct employment to about 100 million people around the world, asserts that "The most important characteristic of fisheries is the common property problem embodying open and free access to the resources. Therefore, a large number of traditional fishing grounds, particularly in coastal waters, are being overexploited".

\footnotetext{
-We thank Brian Copeland, Mukesh Eswaran, Gordon Munro and Tony Scott for very helpful comments and Carol McAusland for research assistance. We also thank seminar participants at U.B.C., the University of Washington, and at the 1994 Canadian Economic Association meetings in Calgary. Financial support from the Social Sciences Research Council of Canada and the UBC. Centre for International Business Studies is gratefully acknowledged.

${ }^{1}$ In the early literature on renewable resources, the term "common property" was often used as if it necessarily implied open access. It is now standard in resource economics to distinguish between "common property", which is simply property that is collectively owned, and "open access", which refers to an inability to restrict access to the resource. Common property may or may not be subject to open access. It is, of course, open access, not collective ownership per se, that gives rise to market failure.
} 
In cases where renewable resource harvests are exported, there is often particular emphasis on the effect of international trade on renewable resource management. For example, Bee (1987) asserts that from 1948 to 1975 forests in the Phillipines were treated as "wasting assets rather than renewable resources" and that international trade was a factor contributing to the high harvest rates in this period. ${ }^{2}$ There is now considerable interest in incorporating trade rules focused on resource management into the General Agreement on Tariffs and Trade (or its proposed successor, the World Trade Organization) and other international agreements. ${ }^{3}$

Our objective in this paper is to examine the relationship between international trade and open access renewable resources. A full characterization of the interaction between international openness and renewable resource management is beyond the scope of any one paper, and our objective in this paper is necessarily fairly modest. Specifically, we consider the effects of trade on a small country with a nationally-owned open access renewable resource, using a simple twogood general equilibrium model. We characterize the determinants of comparative advantage for such a case, and we examine the circumstances under which free trade will raise or lower welfare for the small country.

Focusing on the small country case and assuming that the resource is nationally owned rather than trans-boundary limits the scope of the analysis, but these assumptions seem like a natural starting point. We note in passing that most open access renewable resources of current

\footnotetext{
${ }^{2}$ Annual lumber production rose from about one thousand cubic meters in the early 1950 s to 11.5 million cubic meters in 1969, at which point lumber accounted for 35\% of Phillipine exports. Production fell sharply over the following decade, due largely to depletion, and lumber accounted for only $4.6 \%$ of exports by 1983 , based on production of 5.5 million cubic meters.

${ }^{3}$ GATT does some monitoring of resource management through its Trade Policy Review Mechanism. The GATT FOCUS Newsletter of March-April 1994 reviews Iceland and observes that " ... almost free-of-charge access to the fishing grounds... had encouraged over-expansion of the fleet and over-fishing."
} 
interest are nationally owned, including almost all forest stocks and pastureland and most inland and coastal fisheries.

One of the two goods is a resource good produced using labor and the resource stock. The other good is a generic "manufactures" good produced using just labor. The closed economy version of the model is a natural general equilibrium extension of the canonical Schaefer (1957) renewable resource model which has not, to our knowledge, been previously studied. The closed economy model is of some interest in itself and could potentially be used for a range of applications. We show, for example, that technical progress in resource-harvesting can be welfare-reducing. Our main focus, however, is on international trade. To trade theorists, the model will look much like a two-good Ricardian model where at every point in time relative prices are determined by relative labor productivities alone. The evolution of these temporary Ricardian equilibria is, however, driven by factor endowment considerations.

As a necessary preliminary to our discussion of trade we use the closed economy model to characterize the determinants of autarky relative prices or "comparative advantage." We then assume that the parameters of the model are such than a non-trivial autarkic steady state exists, and allow the country to participate in world markets at fixed world prices.

We are able to show that comparative advantage is determined by the ratio of a biological paramater, $r$, referred to as the the "intrinsic" resource growth rate, to labor, denoted by $L$. If we considered two hypothetical countries with the same ratio of $r$ to $L$ (and with identical homothetic preferences), then they would share the same autarky prices, independent of scale. For some sufficiently high ratio of $r / L$, a country would have an autarky price of the resource good less than the world price, and can therefore be referred to as "resource abundant" relative to the 
world as a whole. Whenever a country is resource abundant in this sense, it exports the resource good as trade opens, and in steady state. Conversely, a sufficiently low ratio of $r / L$ implies that the autarky relative price for the resource good exceeds the world price. Such a country will import the resource good as trade opens and in steady state.

We also show how the pattern of specialization and trade determine the welfare implications of trade. If the small country imports the resource good, then it must gain from trade. Notably, however, if the small country exports the resource good yet remains diversified in production, its steady state welfare is unambigously reduced by trade.

If the small country specializes in production of the resource good, it may still suffer steady state losses from trade. Only if the world price of the resource good is sufficiently high, and the domestic labor force sufficiently small, can the small country obtain steady-state gains from trade. Thus we have the unusual result that the small country's steady-state welfare may be U-shaped in the terms of trade. International trade at low or very high world relative prices for the resource good would be welfare-improving, but intermediate levels would reduce steady-state welfare.

This paper draws on the literature on renewable resource economics. This literature is too large to attempt to cite in any detailed fashion. Valuable overviews (including a good deal of original work) include Clark (1990), Dasgupta and Heal (1979), Munro and Scott (1985), and Neher (1990). Classic early papers include Gordon (1954), Scott (1955), and Schaefer (1957). The literature on trade in renewable resources seems comparatively modest in scope. The review article on trade and resources by Kemp and Long (1984) is devoted mostly to non-renewable resources and has relatively little coverage of trade in renewable resources. The early papers most 
closely related to ours are McRae (1978) and Scott and Southey (1969), both of which consider trade involving open access renewable resources. Other early papers on trade and renewable resources include Markusen (1976) and Tawada (1982). More recent papers include Chilchilnisky (1993) and Rauscher (1992).

Our contribution differs from previous work in three significant ways. Most obviously, we focus on the open access case, whereas much of the existing literature on renewable resources has focused on optimal exploitation, implictly assuming that property rights are adequately enforced. (Scott and Southey (1969), Markusen (1976), and McRae (1978) are notable exceptions). While optimal exploitation is of interest, it also seems important to understand cases in which property rights are less than complete, especially if we are considering low income countries. Secondly, given the structure of our model, we are able to characterize comparative advantage, trade patterns, and welfare effects as functions of a simple primitive that corresponds to relative factor abundance, $\mathrm{r} / \mathrm{L}$. Earlier work has not identified this ratio as a key primitive in understanding renewable resource models. Finally, our model allows us to move beyond the uninformative statement that trade may or may not improve welfare in a distorted economy to a clear identification of the necessary and sufficient conditions for trade to be welfare-improving. ${ }^{4}$

The remainder of the paper proceeds as follows. Section 2 sets out the basic model of renewable resource growth and introduces the open access assumption. Section 3 develops a closed economy model incorporating an open access renewable resource. Section 4 contains the

\footnotetext{
${ }^{4}$ Our paper fits into the large general category of papers dealing with the effects of trade in economies with existing distortions. In particular, some of our results bear a structural resemblance to those found in the literature on the effect of increasing returns to scale on trade flows and welfare levels (see Helpman (1984) for a review).
} 
analysis of the small open economy case. Section 5 describes the effects of generalizing certain assumptions of the model, and section 6 offers concluding remarks.

\section{The Open Access Renewable Resource Model}

Before proceeding to the general equilibrium setting, it is useful to describe the basic structure of renewable resource growth. We have in mind a renewable resource such as a forest or a fish species. The stock of the resource at time $t$ is denoted $S(t)$. The natural growth rate of the resource, $G$, is taken to be a function of the existing stock. The change in the stock at time $t$ is the natural growth rate, $G(S(t))$, minus the harvest rate, $H(t)$.

$$
\mathrm{d} S / \mathrm{dt}=\mathbf{G}(\mathbf{S}(\mathrm{t}))-\mathrm{H}(\mathrm{t})
$$

Perhaps the simplest empirically plausible form for $\mathrm{G}$ is the logistic function, as given by

$$
G(S)=r S(1-S / K) .
$$

The variable $\mathrm{K}$ is the maximum possible size for the resource stock and is referred to as the "carrying capacity" of the resource. If stock $\mathrm{S}$ equals $\mathrm{K}$, then the growth rate is zero and further additions to the stock cannot occur. The variable $r$ is the "intrinsic" or "uncongested" growth rate. Note that the proportional growth rate $G(S) / S$ would be approximately equal to $r$ if congestion effects were neglible in the sense that the carrying capacity were very large relative to the current stock.

The functional form for the harvest rate, $\mathrm{H}$, would normally be derived from the economic incentives (or other decision rules) that control the behaviour of harvestors. One important possibility, first analyzed by Gordon (1954), is that the resource might be a common property resource subject to open access. Under such conditions, harvesting occurs up to the point at which the current return to a representative entrant is just equal to the entrant's current cost. No 
harvestor has an incentive to delay harvesting as long as positive current rents are available, because of the legitimate expectation that someone else will harvest the resource instead. While we might believe that incomplete property rights would often manifest themselves in a less extreme fashion than complete open access ${ }^{3}$, the issues raised by poor resource management arise most starkly, and therefore most clearly, in this setting.

\section{General Equilibrium with a Renewable Resource: Autarky}

We now introduce an explicit Ricardian general equilibrium setting for a country with a nationally-owned open access renewable resource. The country can potentially engage in trade, but we first examine the no-trade or autarkic equilibrium. We use explicit functional forms that allow us to obtain closed-form solutions for various quantities of interest. Despite the use of specific functional forms, much of the analysis can be readily generalized, as discussed in Section 5.

\subsection{Production and Supply:}

The country produces and consumes two goods. $\mathrm{H}$ is the harvest from a renewable resource. $\mathrm{M}$ is some other good which might be thought of as manufactures. Good $\mathrm{M}$ is treated as the numeraire whose price is normalized to 1 . Aside from the stock of the renewable resource, $S$, there is only one additional factor of production, labor, L. Manufactures are produced using labor as the only input. By choice of units, one unit of labor produces one unit of good M. As the price of good $\mathrm{M}$ is 1 , it follows that labor's value of marginal product in manufacturing is 1 .

\footnotetext{
${ }^{5}$ Among those papers that do consider incomplete property rights, almost all consider the open access case (as we do), which is the other extreme. Thus there is little work on cases of incomplete property rights with less than open access. One recent exception that deals with effects of costly access under duopoly is Mason and Polansky (1994).
} 
We assume that harvesting of the resource is carried out according to the Schaefer harvesting production function, which is written as follows,

$$
\mathbf{H}^{\mathrm{P}}=\alpha \mathrm{SL}_{\mathrm{H}}
$$

where $L_{H}$ is the amount of labor used in resource harvesting and $\alpha$ is a positive constant (the superscript $\mathbf{P}$ stands for production). We let $a_{L H}(S)$ represent unit labor requirements in the resource sector. From (3), unit labor requirements are

$$
a_{L H}(S)=L_{H} / H^{P}=1 / \alpha S
$$

Note that $a_{L H}(S)<0$. As the resource stock falls, unit labor requirements rise.

The combination of the Schaefer harvesting production function and logistic growth of the resource is often referred to as the Schaefer model (after Schaefer (1957)). ${ }^{6}$ The Schaefer harvesting production function implies that, at a moment in time, production of the harvest is much like production of manufactures. Given the stock size, if we double labor input, we double the harvest rate. To have any actual effect on the stock, this harvest rate has to continue over some positive interval of time. ${ }^{7}$

Production in both sectors is carried out by competitive profit-maximizing firms under conditions of free entry. Thus the price of the resource good must equal its unit cost of production. It follows that

$$
p=w_{a_{L H}}=w / \alpha S
$$

\footnotetext{
${ }^{6}$ The Schaefer model has a long history in the renewable resources literature starting with Gordon (1954). It is commonly used in the literature. See, for example, the review article by Munro and Scott (1985).

${ }^{7}$ See Gordon (1954, pp. 139-140) for a defense of instantaneous constant returns to the variable factor. Diminishing returns to the variable factor arise intertemporally through the adjustment of the stock, $S$.
} 
where $w$ is the wage. The condition that $p=w a_{L H}$ incorporates the open-access assumption, because it means that labor costs are the only explicit cost of production. There is no explicit rental cost for using $\mathbf{S}$.

Labor markest are competitive, and labor is freely mobile, implying that both sectors must have the same wage. Hence, if manufactures are produced, it follows that $w=1$, and (4) becomes

$$
p=1 / \alpha S
$$

\subsection{Utility, Consumption, and Demand:}

A representative consumer is endowed with one unit of labor and is assumed to have instantaneous utility given by the following Cobb-Douglas utility function

$$
u=h^{\beta} m^{1-\beta}
$$

where $h$ represents individual consumption of the resource good, $m$ is individual consumption of manufactures, and taste paramter $\beta$ is strictly between 0 and 1 . The representative consumer maximizes utility at each moment in time subject to the instantaneous budget constraint given by:

$$
\mathrm{ph}+\mathrm{m}=\mathrm{w}
$$

As is well-known, taking $\mathrm{p}$ and $\mathrm{w}$ as exogenous and maximizing (5) subject to (6) yields the demand functions $h=w \beta / p$ and $m=w(1-\beta)$. Noting that aggregate demands for $H$ and $M$ are given by $\mathrm{H}^{\mathrm{c}}=\mathrm{hL}$ and $\mathrm{M}^{\mathrm{C}}=\mathrm{mL}$, we find:

$$
H^{C}=w \beta L / p ; M^{c}=w(1-\beta) L
$$

where the $\mathrm{C}$ superscript stands for consumption. It is useful to rewrite the demand for $\mathrm{H}$ in inverse form:

$$
p=w \beta L / H^{c}
$$


Note that with Cobb-Douglas preferences both goods are "essential". Since good $\mathbf{M}$ is essential and cannot be exhausted, it will always be consumed. Therefore, in autarky, $M$ must be produced and the autarky wage must be 1 .

\subsection{Ricardian Temporary Equilibrium}

At a moment in time the resource stock $\mathbf{S}$ is fixed, and the economy is Ricardian. The full employment condition given by

$$
\mathrm{H}^{\mathbf{P}} \mathrm{a}_{\mathrm{LH}}(\mathbf{S})+\mathbf{M}=\mathbf{L}
$$

defines a standard Ricardian production possibility frontier. Substituting (3a) into (9) and rearranging yields

$$
\mathrm{H}^{\mathrm{P}}=\alpha \mathbf{L S}-\alpha \mathbf{S M}
$$

The temporary equilibrium can be solved algebraically by setting the supply price given by (4) equal to the demand price given by (8). Equating the two prices and solving for $\mathrm{H}$ yields

$$
\mathbf{H}=\alpha \beta \mathbf{L S}
$$

We refer to expression (11) as the "harvest schedule" since it gives us the temporary equilibrium harvest for any given resource stock. The equilibrium output of $M$ is simply $M=(1-\beta) L$, and hence a fraction $\beta$ of the labor force is employed in the resource sector.

The temporary equilibrium just described is much like a standard Ricardian equilibrium, except that the vertical intercept of the production possibility frontier depends on the stock, $S$, as does the equilibrium value of $\mathrm{H}$. At any temporary equilibrium there is no guarantee, of course, that the harvest will equal the underlying biological growth rate of the resource. The next step, therefore, is to consider the interaction between the temporary Ricardian equilibrium and the evolution of the resource stock. 


\subsection{Transition to the Steady-state}

In Figure 1 we combine our temporary equilibrium harvest schedule $H(S)$ (from(11)) with the logistic growth equation $G(S)$ (from (2) ) to trace the evolution of the resource stock. A characterization of the transition path and the conditions necessary for a steady state to exist are given in Proposition 1. Figure 1 illustrates a situation where the initial stock level, $S_{0}$, leads to a harvest, $H\left(S_{0}\right)$, in excess of the natural growth rate, $G\left(S_{0}\right)$. Accordingly, the stock shrinks toward the autarkic steady state level, denoted $\mathbf{S}^{\mathbf{A}}$.

\section{Figure 1: Resource Dynamics}

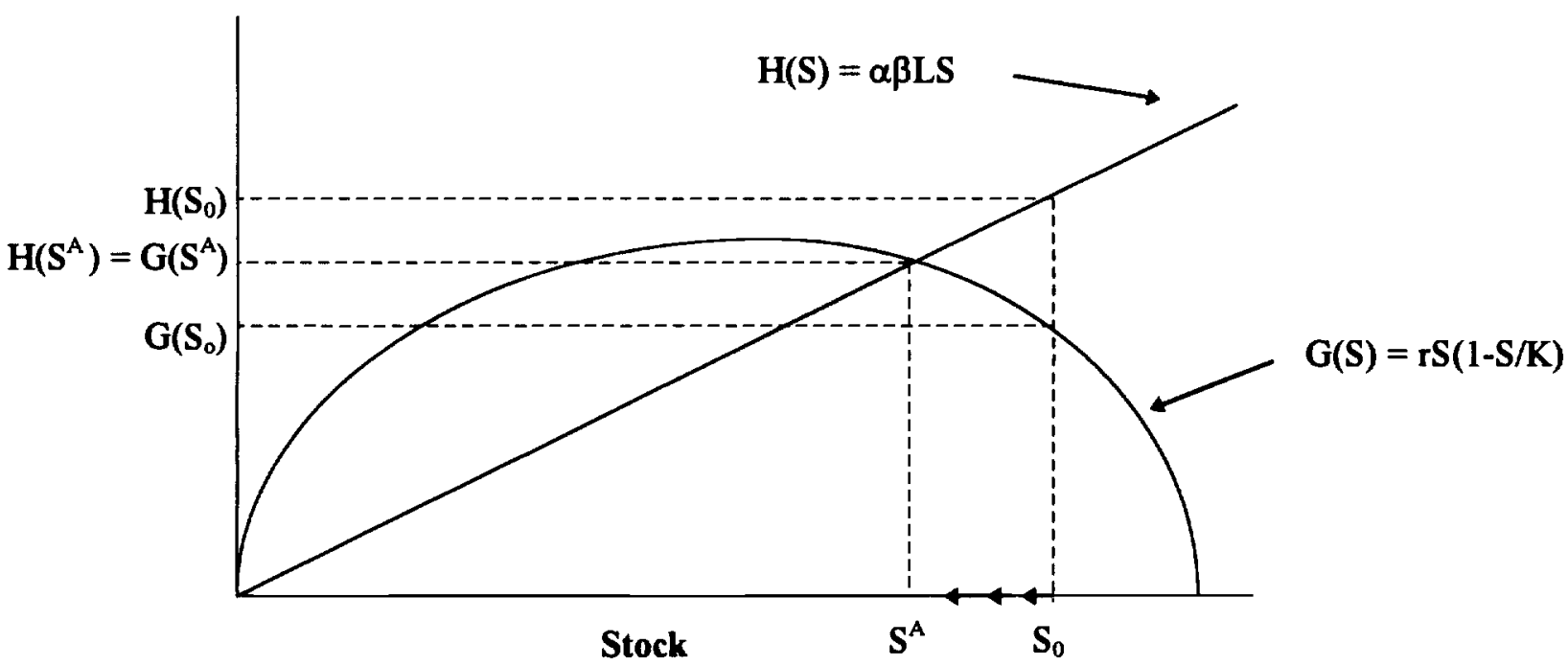

The steady-state harvest is illustrated by the point at which the harvest schedule intersects the growth curve in Figure 1. At the point of intersection, dS/dt (given by (1)), is zero. As drawn, this solution is to the right of the "maximum sustainable yield" (MSY) given by the peak of the growth curve, but it could in principle also be to the left of MSY or at MSY.

Figure 2 illustrates the corresponding transition of a Ricardian temporary equilibrium toward the steady state. At some initial resource stock, $S_{0}$, the associated harvest is $H\left(S_{0}\right)$. As the 
resource stock shrinks toward the autarky steady state level, $\mathbf{S}^{\mathbf{A}}$, production function (3) implies that labor productivity in the resource sector falls and the vertical intercept of the production possibility frontier moves down the vertical axis, inducing an inward pivot of the frontier, as shown. The resource stock continues to shrink until the temporary equilibrium harvest falls to a level equal to the underlying natural growth of the resource, as represented by $H\left(S^{A}\right)$.

Figure 2: Temporary Equilibrium Dynamics

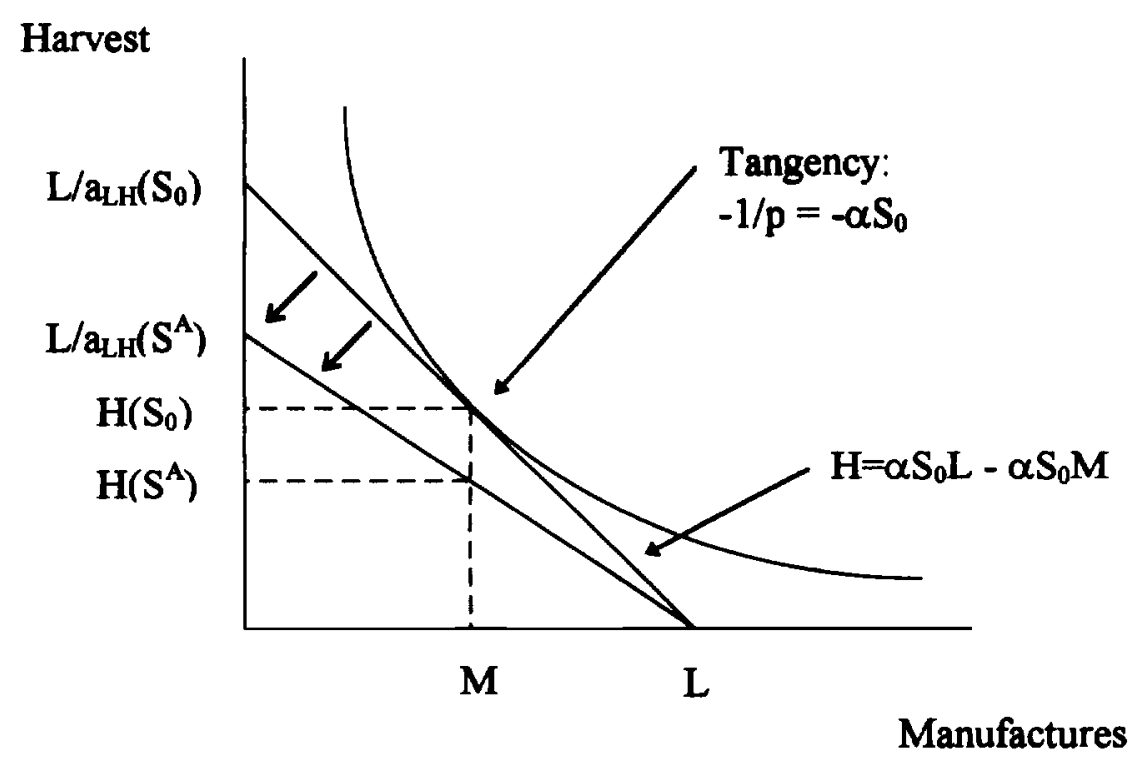

Because utility is Cobb-Douglas, consumption of $M$ is unaffected by the resource stock adjustment. More generally, consumption of both manufactures and the resource good would change as the stock adjusted.

To solve for the steady state stock, we note that the temporary equilibrium condition (11) must be satisfied and, in addition, $\mathrm{dS} / \mathrm{dt}$ as given by (1) must be zero. This implies that the harvest given by (11) must equal the resource growth rate given by (2), yielding

$$
\alpha \beta L S=r S(1-S / K)
$$


Solving this equation for $S$ gives the autarkic steady state resource stock, $S^{A}$.

$$
S^{A}=K(1-\alpha \beta L / r)
$$

Substituting the value of S given by (13) into conditon (4a) allows us to solve for the steady state autarky price, $\mathrm{p}^{\mathbf{A}}$. This solution is

$$
\mathrm{p}^{\mathrm{A}}=\frac{1}{\alpha \mathrm{K}\left(1-\alpha \beta \frac{\mathrm{L}}{\mathrm{r}}\right)}
$$

Finally, to obtain the steady-state harvest, we substitute (13) into (11) to find

$$
H=\alpha \beta \operatorname{LK}(1-\alpha \beta L / r) \text {. }
$$

It is apparent from (13) and (15) that a steady-state with positive stock and harvest levels will not exist for all parameter values. The main parameter restriction is given in Proposition 1.

\section{Proposition 1:}

i) For all parameter values, a possible steady state exists at $\mathbf{S}=\mathbf{H}=\mathbf{0}$.

ii) Starting from a positive initial stock, a steady-state solution with a positive stock exists if and only if

$$
\mathrm{r} / \mathrm{L}>\alpha \beta \text {. }
$$

iii) If a positive autarkic steady state stock, $S^{A}$, exists, then it is the unique positive solution, it is globally stable, and convergence to this steady state from any initial positive stock is monotonic (i.e. $d S / d t>0$ for all positive stock levels less than $S^{A}$ and $d S / d t<0$ for all $S>S^{A}$ ).

iv) If (16) is not satisfied, the resource will be extinguished and the unique steady state is $\mathbf{S}=\mathbf{H}$ $=0$.

Proof: i) follows from inspection of equation (2). If $S=0$, no resource growth is possible, so this must be a steady state. ii) follows from the observation that $S^{A}$ in expression (13) is positive if and 
only if (16) holds. iii) follows from inspection of Figure 1, but it is useful to characterize the evolution of $S(t)$ exactly. The dynamics of our autarky model are governed by equation (1), which implies that $d S / d t=r S(1-S / K)-\alpha \beta L S$, subject to $S(t=0)=S_{0}$. This non-linear differential equation can be transformed into a linear equation by the change of variables $S=1 / \mathrm{V}$. Solving the transformed linear equation shows that

$$
S(t)=1 /\left(b / a+c e^{-a t}\right)
$$

where $a=r-\alpha \beta L, b=r / K$, and $c=\left(1 / S_{0}-b / a\right)$. Taking the derivative of $S(t)$ with respect to $t$ shows that $d S / d t>0$ if $S_{0}<S^{A}$ (as given by (13)), and dS/dt $<0$ if $S_{0}>S^{A}$. Provided (16) holds, the adjustment of the stock proceeds monotonically toward $\mathrm{S}^{\mathrm{A}}$, implying both stability and monotonicity.

iv) is implied by (i) and (ii). It can also be inferred from Figure 1. ${ }^{* * *}$

This proposition can be readily understood by noting that condition (16) means that the harvest schedule in Figure 1 must lie inside the growth curve. The slope of the harvest schedule is $\alpha \beta L$, while the slope of the growth curve at $S=0$ is $r$. Condition (16) can be rewritten as $\alpha \beta L<$ $r$, implying that the slope of the harvest schedule must be less than the slope of the growth curve at the origin. If so, there is a unique, stable, positive solution. Otherwise, the harvest line will lie above the growth curve, implying that the harvest will exceed the underlying resource growth rate for all positive stock levels, leading to extinction of the resource.

\subsection{Comparative Steady States}

We can see from differentiation of equations (13) - (15) with respect to $r$ and $K$ than an increase in intrinsic growth rate $\mathrm{r}$ or carrying capacity $\mathrm{K}$ would increase steady state stock and 
harvest levels, while reducing the price of the resource good. The comparative steady state effects of changes in $\alpha, \beta$, and $\mathrm{L}$ are slightly more subtle, as described in Proposition 2 .

Proposition 2: An increase in conditional labor harvesting productivity, $\alpha$, taste parameter $\beta$, or labor supply $\mathrm{L}$ will

i) lower the steady-state resource stock,

ii) increase the steady-state harvest if $r / L>2 \alpha \beta$, and decrease the steady-state harvest ${ }^{8}$ if $r / L<$ $2 \alpha \beta$.

iii) An increase in $\beta$ or $L$ will increase the steady state relative price of the resource good.

iv) An increase in $\alpha$ will increase the resource good price if $r / L<2 \alpha \beta$ and decrease it if $r / L>$ $2 \alpha \beta$.

v) A sufficiently large increase in $\alpha, \beta$, or $\mathrm{L}$ will cause extinction of the resource.

Proof: Results i-iv follow from differentiation of expressions (13)-(15). We report the algebra just for $\mathrm{dH} / \mathrm{d} \alpha$, as the other effects are derived in similar fashion. Differentiating (15) with respect to $\alpha$ yields

$$
\mathrm{dH} / \mathrm{d} \alpha=\beta \mathrm{LK}-2 \alpha \mathrm{K}(\mathrm{L} \beta)^{2} / \mathrm{r}=\beta \mathrm{LK}(1-2 \alpha \beta \mathrm{L} / \mathrm{r}) .
$$

From (18) it follows that whether $\mathrm{dH} / \mathrm{d} \alpha$ is positive or negative depends on the sign of 1 $2 \alpha \beta \mathrm{L} / \mathrm{r}$, which depends in turn, on whether $\mathrm{r} / \mathrm{L}$ exceeds or falls short of $2 \alpha \beta$, as was to be shown. Result v) follows from the observation that if $\alpha, \beta$, or $L$ increases sufficiently, then eventually $\alpha \beta$ will exceed $\mathrm{r} / \mathrm{L}$, violating condition (16), which implies that extinction will occur in finite time. ${ }^{* * *}$

\footnotetext{
${ }^{8}$ These two possibilities arise because the steady state supply curve for the resource good is backward bending. See Copes (1970) or Scott and Southey (1969) for early demonstrations of the backward-bending supply property for open-access renewable resources.
} 
These effects can be understood using Figure 1 . The condition that $r / L<2 \alpha \beta$ can be rewritten as $\alpha \beta L>r / 2$, where $\alpha \beta L$ is the slope of the harvest schedule in Figure 1. If slope $\alpha \beta L$ is less than $\mathrm{r} / 2$, then the harvest schedule must intersect the growth curve on its downwardsloping portion, as drawn. In this case, a small increase in $\alpha, \beta$, or $L$ causes the slope of the harvest schedule to increase, making the harvest schedule pivot upward slightly. The new intersection between the harvest schedule and the growth curve is therefore slightly higher on the growth curve, implying that the steady state harvest will increase, while the steady state stock diminshes. If, alternatively, $\alpha \beta L>r / 2$, then the harvest schedule will intersect the growth curve on its upward-sloping part, implying that a small increase in $\alpha, \beta$, or $\mathrm{L}$ would induce a steadystate decline in both the stock and the harvest. Sufficiently large increases in $\alpha, \beta$, or $\mathrm{L}$ will cause $\alpha \beta L$ to exceed $r$, violating condition (16), and causing the harvest schedule to lie above the growth curve, leading to extinction of the resource.

It is perhaps not surprising that a sufficiently large increase in L (representing population increase) would cause extinction. After all, resource capacity is finite, and will eventually be swamped by population growth. It is somewhat more striking that improvements in harvesting technology, reflected by increases in $\alpha$, may be damaging or even catastrophic, given the underlying open-access market failure. ${ }^{9}$

\footnotetext{
${ }^{9}$ The U.S. passenger pigeon was hunted to extinction in the 19th century following improvement in hunting efficiency (better rifles). (Thanks to Gardner Brown for this example.) Similarly, the blue whale was hunted to near extinction during the period 1930-1960 as a result of improved whaling technology. It is estimated that there were approximately 250,000 blue whales at the beginning of the 20th century. The most recent (mid-1994) estimates put the blue whale population at about 500 .
} 


\section{$\underline{\text { 3.6 Factor Proportions }}$}

For a positive steady state harvest to exist, the economy must be sufficiently "resource abundant" in the sense that $r / L$ must be sufficiently large. From (2) it is apparent that the flow of services from any positive resource stock, measured by the sustainable harvest it can support, is proportional to the intrinsic growth rate $r$. In essence, $r$ represents the flow of services available from the resource stock. Variable $L$ is the flow of labor services. The ratio $r / L$ can then be viewed as measuring the relative factor service flow.

From equation (14) we see that equiproportionate increases in the labor force and in the intrinsic rate of resource growth leave autarky relative prices unchanged. ${ }^{10}$ Comparative advantage, as reflected by autarky prices, is determined by the composition of factor flows in that an increase in the relative resource abundance of the economy, as measured by $r / L$, lowers the relative price of the resource good. A decrease in $r / L$ raises this relative price. Therefore, the steady-state properties of the model are closely related to factor proportions, as in models of the Heckscher-Ohlin type, even though the model is Ricardian at each moment in time.

\section{The Small Open Economy}

\subsection{The Temporary Equilibrium Pattern of Production and Trade}

We consider an economy that is small in the sense that the world relative price of the resource good can be taken as exogenous. We denote this world price as $p^{*}$. We assume that the small country is at an initial autarkic steady state, then becomes open to trade. When trade opens,

\footnotetext{
${ }^{10}$ The intuition is as follows. Starting from a steady state, consider a doubling of both $\mathrm{L}$ and $\mathrm{r}$. On impact, as tastes are homothetic, the demand for both goods doubles because income, $w L=L$, doubles. Also, the temporary equilibrium harvest and the production of manufactures both double. Thus the current demand and current supply of each good doubles, leaving relative prices unchanged. We can also see that this new temporary equilibrium is sustainable as a steady state, because doubling $\mathrm{r}$ also doubles the sustainable harvest for the given resource stock. It follows that this new temporary equilibrium is a new steady state as well.
} 
the temporary pattern of production in the country is determined soley by the relative returns to labor in the two sectors. As trade opens, the resource stock is at its autarky level, $\mathrm{S}^{\mathrm{A}}$. Therefore, from (3), the marginal product of labor in the resource sector is $\alpha \mathrm{S}^{\mathrm{A}}$. The new wage available in the resource sector is simply the value of marginal product, which is the world price times the marginal product: $\mathrm{p}^{*} \alpha \mathrm{S}^{\mathrm{A}}$. If this wage exceeds 1 (the wage available in the manufacturing sector) then all workers move to the resource sector, and the economy will temporarily specialize in production of the resource good. Conversely, if $p^{*} \alpha S^{A}<1$, then all workers will move to the manufacturing sector. If $\mathrm{p}^{*} \alpha \mathrm{S}^{\mathrm{A}}=1$, the initial temporary equilibrium pattern of production is indeterminate, as workers are indifferent between the two sectors. The production pattern can be readily linked to the comparison of autarky and world prices, as described in Proposition 3.

\section{Proposition 3:}

In the initial temporary equilibrium following the opening of trade, the small economy will

i) specialize in and export the resource good if $\mathrm{p}^{*}>\mathrm{p}^{\mathrm{A}}$,

ii) specialize in and export manufactures if $\mathrm{p}^{*}<\mathrm{p}^{\mathrm{A}}$, and

iii) have an indeterminate pattern of trade and production if $\mathrm{p}^{*}=\mathrm{p}^{\mathrm{A}}$.

Proof: (i) From (4a) we know that $p^{A}=1 / \alpha S^{A}$, or $p^{A} \alpha S^{A}=1$. Therefore, if $p^{*}>p^{A}$, then $p^{*} \alpha S^{A}$ $>1$, implying that the value of marginal product (and the wage) available in the resource sector exceeds 1 , which in turn implies that the small country specializes in the resource good. Since both goods are essential and prices are finite, both goods must be consumed, implying that the resource good must be exported so as to obtain imports of manufactures. Cases ii) and iii) follow by parallel reasoning. ${ }^{* * *}$ 
Provided that the world price differs from the autarky price, the autarky resource stock, $\mathrm{S}^{\mathrm{A}}$, will not be consistent with a trading steady state. Following the opening of trade, the resource stock will evolve toward a new steady state. It is useful to consider the case of $p^{*}>p^{A}$ (comparative advantage in the resource sector) and $\mathrm{p}^{*}<\mathrm{p}^{\mathrm{A}}$ (comparative advantage in the manufacturing sector) separately.

\subsection{Transition to a Steady State for a Resource Abundant Country $\left(\mathrm{p}^{*}>\mathrm{p}^{\mathrm{A}}\right)$}

The movement to a new steady state for the case $\mathrm{p}^{*}>\mathrm{p}^{\mathrm{A}}$ can be readily understood using Figure 3. When trade opens, the economy's production possibility frontier has a vertical intercept at $L / a_{L H}\left(S^{A}\right)$, which equals $L \alpha S^{A}$, and a horizontal intercept at $L$. If $p^{*}>p^{A}$, then, as described in Proposition 3, the economy immediately specializes in the resource good and the temporary equilibrium production point moves to the vertical axis at $L \alpha S^{A}$. Hence, the economy's initial free trade budget line has vertical intercept $L \alpha S^{A}$ and slope $-1 / p^{*}$, as shown. The new temporary equilibrium consumption point must lie on the budget line above and to the right of the autarky consumption point, at point $\mathrm{C}$. Thus, when trade opens, this economy exports the resource good, imports manufactures, and experiences temporary gains from trade.

Figure 3: Transition to a Trading Steady State

Harvest

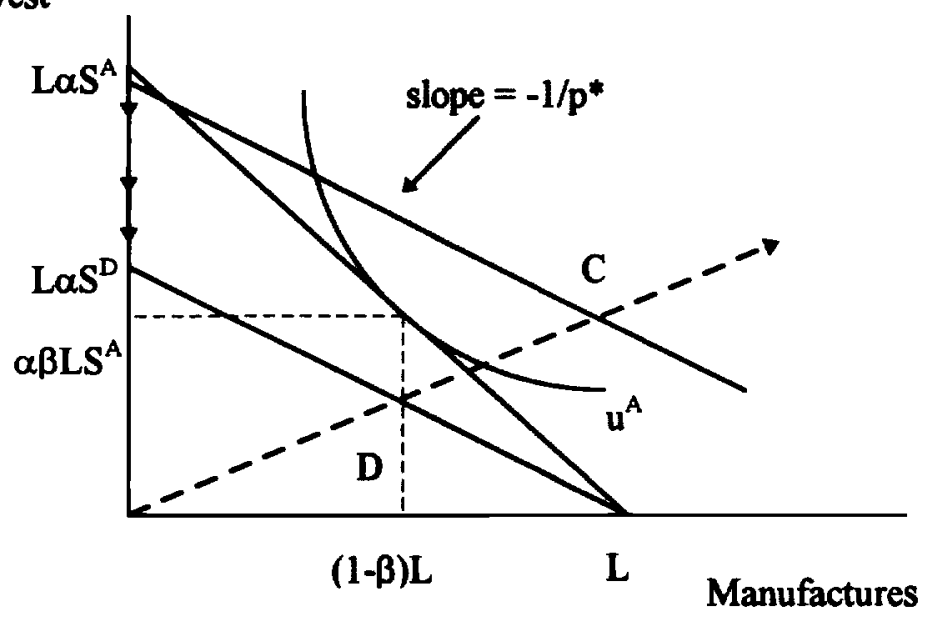


At the initial temporary equilibrium, all labor has entered the resource sector, implying that the temporary harvest rate has risen above the steady state autarky level. (Recall that in autarky only fraction $\beta$ of the labor force was employed in the resource sector.) Thus the harvest rate exceeds the growth rate of the resource and the resource stock diminishes. As the resource stock shrinks, labor productivity in the resource sector falls in accordance with equation (3), and the vertical intercept of the production possibility frontier moves down along the vertical axis as shown by the arrows. As production of the harvest falls along this transition path, so too does the economy's free trade budget line. Exports of the resource good, imports of manufactures, and the economy's gains from trade shrink as time progresses.

The exact time pattern of stock adjustment, and its consequent effect on production, utility, and trade flows can be worked out quite readily. The evolution of the stock $\mathrm{dS} / \mathrm{dt}$ during the transition phase is, as before, governed by (1), which implies, in this case, that $\mathrm{dS} / \mathrm{dt}=\mathrm{rS}(1-$ $\mathrm{S} / \mathrm{K}$ ) - $\alpha \mathrm{LS}$. (This is as in autarky with $\beta$ being replaced by 1 , reflecting the fact that all of the labor force is now active in harvesting). Also the initial condition in this case is $S(0)=S^{A}$. The transition path is described by the following equation. ${ }^{11}$

$$
S(t)=1 /\left(b / a+c e^{-a t}\right)
$$

where $a=r-\alpha L, b=r / K$, and $c=\left(1 / S^{A}-b / a\right)$. As implied by $(17 a)$, the stock declines monotonically over time, as does labor productivity in the resource sector (and output) until either the value of marginal product in the resource sector is driven to 1 , allowing diversified production, or the resource stock stabilizes at a new (lower) level that can support the country's

\footnotetext{
${ }^{11}$ Strictly speaking, this equation describes the transition path as long as the economy remains specialized in the resource good. The economy does remain specialized until the steady-state harvest is reached. In the case of diversification, some labor shifts out of the resource sector at this point.
} 
entire labor force at a wage exceeding 1 . These two cases correspond to diversification and specialization, respectively. Either outcome is possible, depending on conditions to be specified in Proposition 7.

Figure 3 illustrates the case of steady state diversification, in that the steady state production frontier is drawn parallel to the initial budget line. Therefore, the steady state free trade budget line is coincident with the production possibility frontier, and the economy consumes at point $\mathbf{D}$. Under the assumption of Cobb-Douglas utility (or homothetic utility more generally), the steady state consumption point, $D$, must lie on the same ray from the origin as the initial temporary consumption point, C. Moreover, point D must also correspond to the same consumption of good $M$ as in autarky because national income measured in terms of good $M$ is identical in the two cases, and preferences are Cobb-Douglas. As a result, during the transition phase to the steady state, the economy's free trade consumption point must lie along the same ray through $\mathrm{D}$ and $\mathrm{C}$.

The steady state stock supporting a diversified trading steady state is denoted $\mathbf{S}^{\mathrm{D}}$. In order for $S^{D}$ to support diversified production, it must be the case (from (4a)) that

$$
S^{D}=1 / \alpha p^{*}
$$

or, equivalently, $\mathrm{p}^{*} \alpha \mathrm{S}^{\mathrm{D}}=1$. This implies that the value of marginal product is 1 in the resource sector and therefore equal to the value of marginal product in the manufacturing sector. The temporary pattern of production is indeterminate, but there is only one division of labor across sectors that is consistent with a steady state. Labor has to be divided across sectors so that the current harvest is just equal to the natural growth rate. If more labor moved into the resource sector, the resource stock would fall and with it the value of labor's marginal product in 
resources. Workers would move into manufacturing and this would rebuild the stock and reestablish the previous equilibrium. Conversely, if labor moved out of resources and into manufacturing then the stock of the resource would grow, the value of marginal product in the resource sector would rise, and this would drive workers back into the resource sector. Consequently, the steady state pattern of production is determinate, and the diversified steady state is stable.

It is apparent from Figure 3 that if $p^{*}>p^{A}$, and a diversifed steady state emerges, then the small country's steady state utility is reduced by international trade. This follows directly from the fact that the consumption possibility set in autarky dominates that in the diversified trading steady state. It is also apparent from Figure 3 that the initial or impact effect of trade is to provide temporary gains from trade, but these gains are eroded over time as the economy moves from consumption point $\mathrm{C}$ toward consumption point $\mathrm{D}$. Given this time pattern of early gains followed by eventual losses, there is some positive discount rate such that if future utility is discounted at this rate or less, then the present discounted value of utility is reduced by trade.

Finally, note that this country exports the resource good and imports manufactures during the entire transition phase toward the steady state. Once the economy shifts to diversification as the steady-state stock is reached, however, it is no longer obvious from the diagram that the country will still export the resource good. This can, however, be shown algebraically.

The simplest way to proceed is to compare the country's steady state supply of the resource good with its steady state demand. Steady state supply must, by the definition of the steady state, equal the natural growth rate given by (2). Thus production, $H^{P}=r S^{D}\left(1-S^{D} / K\right)$, where $S^{D}$ is given by (19). In addition, quantitity demanded and consumed is given by (7) as $H^{C}=$ 
$w \beta L / p^{*}=\beta L / p^{*}$ (noting that $w=1$ whenever manufactures are produced). Taking the difference between $\mathrm{H}^{\mathrm{P}}$ and $\mathrm{H}^{\mathrm{C}}$ yields

$$
\begin{aligned}
H^{P}-H^{C} & =\left(r / \alpha p^{*}\right)\left(1-1 /\left(\alpha p^{*} K\right)\right)-\beta L / p^{*} \\
& =\left(r / \alpha p^{*}\right)\left[1-\alpha \beta L / r-1 /\left(K \alpha p^{*}\right)\right] \\
& =\left(r /\left(K \alpha^{2} p^{*}\right)\right)\left[1 / p^{A}-1 / p^{*}\right]
\end{aligned}
$$

where the transition between the second and third steps makes use of equation (14) for $\mathrm{p}^{\mathrm{A}}$. It follows that the sign of $\mathrm{H}^{\mathrm{P}}-\mathrm{H}^{\mathrm{C}}$ (resource good exports) is the same as the sign of $\mathrm{p}^{*}-\mathrm{p}^{\mathrm{A}}$, leading to Proposition 4.

Proposition 4: If $\mathrm{p}^{*}>\mathrm{p}^{\mathrm{A}}$, and the trading steady state is diversified, then:

i) the small country exports the resource good and imports manufactures

ii) the small country's steady state utility is lower under free trade than in autarky, and

iii) for sufficiently small but positive discount rates, the present discounted value of utility is reduced by trade. ${ }^{* * *}$

Proposition 4 is a strong result, as it shows that when the small country has a comparative advantage in production of the resource good (as defined by the condition that $\mathrm{p}^{*}>\mathrm{p}^{\mathrm{A}}$ ), the open access distortion is made worse by free trade. Moreover, if this country remains diversified in production in the trading steady state, then its steady state utility is driven below autarky levels. However, Proposition 4 represents only one possibility. It is also possible that the small country may specialize in production of the resource good.

\subsection{Transition to a Specialized Steady State for a Resource Abundant Country $\left(p^{*}>p^{A}\right)$}

From Figure 3, we can infer that specialization would result if the resource stock stabilizes at a level that can sustainably support the entire labor force at a wage exceeding 1 . In a 
specialized steady state, the small country's free trade budget line would have a vertical intercept somewhere below $\operatorname{La} \mathrm{S}^{\mathrm{A}}$ and a horizontal intercept at a point on the horizontal axis beyond $\mathrm{L}$. In this case, steady state consumption possibilities in trade do not necessarily dominate those in autarky.

Several results follow immediately from diagrammatic reasoning. First, it is clear that the small country exports the resource good and imports manufactures, both in steady state and at every point along the transition path. Second, if the country's taste for the manufactured good is sufficiently strong then free trade will yield higher utility in steady state (and along the transition path).

In addition, there always exists some $\mathrm{p}^{*}$ high enough to ensure that the small country gains from trade everywhere along the transition path and in steady state. To verify this last assertion note that the utility of a representative consumer is given by (5), and that per capita values of $h$ and $m$ are obtained by dividing the expression in (7) by $L$. Under autarky, we know that $w=1$ and $p=1 / \alpha S^{A}$. Substituting these values into (7) and substituting the result into (5) allows us to write the autarky utility of a representative consumer, denoted $\mathrm{u}^{\mathrm{A}}$, as

$$
\mathbf{u}^{\mathrm{A}}=\left[\beta \alpha \mathrm{S}^{\mathrm{A}}\right]^{\beta}[1-\beta]^{1-\beta}
$$

Denote the resource stock in a specialized equilibrium $\mathrm{S}^{\mathrm{z}}$. From (4) it must be the case that

$$
w=\alpha p^{*}
$$

which must exceed 1. Therefore, under free trade, $h=\beta w / p^{*}=\alpha \beta S^{Z}$ (using (20)) and $m=w(1-$ $\beta)=p^{*} \alpha(1-\beta) S^{z}$. Substituting these values for $h$ and $m$ into (5) yields

$$
u^{T}=\left[\beta \alpha S^{Z}\right]^{\beta}\left[p^{*}(1-\beta) \alpha S^{Z}\right]^{1-\beta}
$$

From (21) and (23) it follows that 


$$
\mathrm{u}^{\mathrm{T}}<\mathrm{u}^{\mathrm{A}} \text { if and only if }\left(\mathrm{S}^{\mathrm{Z}}\right)\left[\alpha \mathrm{p}^{*}\right]^{1-\beta}<\left(\mathrm{S}^{\mathrm{A}}\right)^{\beta}
$$

Note that $S^{A}$ as given by (13) is, of course, independent of $\mathrm{p}^{*}$. We can solve for $\mathrm{S}^{\mathrm{Z}}$ by noting that in a specialized steady state, $H^{P}=\alpha L S^{Z}$ (from (3)). It must therefore be the case that $\alpha \mathrm{LS}^{\mathrm{Z}}=$ r $S^{z}\left(1-S^{z} / K\right)$, from (2). It follows that

$$
S^{z}=K(1-\alpha L / r)
$$

We can see from (25) that $\mathrm{S}^{\mathrm{Z}}$ is also independent of $\mathrm{p}^{*}$. It follows from (24) that steady state utility under free trade can always be made to exceed autarky utility by making $\mathrm{p}^{*}$ sufficiently high. Furthermore, there is some critical value of $p^{*}$, which we denote $p^{r}$, such that $u^{T}$ would just equal $\mathbf{u}^{A}$. The key points from this discussion are summarized in Proposition 5.

Proposition 5: If $\mathrm{p}^{*}>\mathrm{p}^{\mathrm{A}}$, and a specialized steady state arises, then:

i) the small country exports the resource good and imports manufactures

ii) if $\mathrm{p}^{*}>\mathrm{p}^{\mathrm{r}}$ then both steady state utility and the discounted value of utility are increased by trade.

iii) if $\mathrm{p}^{*}<\mathrm{p}^{\mathrm{r}}$ then steady state utility is reduced by trade. The present discounted value of utility may be increased or reduced by trade, depending on the discount rate. ${ }^{* * *}$

We now consider the case in which the small country has a comparative advantage in manufactures (i.e. when $\mathrm{p}^{*}<\mathrm{p}^{\mathbf{A}}$ ).

\subsection{Transition to Steady State for a Resource poor Country $\left(p^{*}<p^{A}\right)$}

Figure 4 depicts the movement of our economy towards a diversified steady state when $p^{*}$ $<\mathrm{p}^{\mathrm{A}}$. When trade opens, the economy immediately specializes in manufactures, as stated in Proposition 3. The initial temporary equilibrium production point moves to the horizontal axis at L. The temporary equilibrium consumption point will lie above and to the right of the autarky consumption point on the free trade budget line with horizontal intercept at $L$, as illustrated. 
Figure 4: Transition to a Trading Steady State for a Resource poor economy Harvest

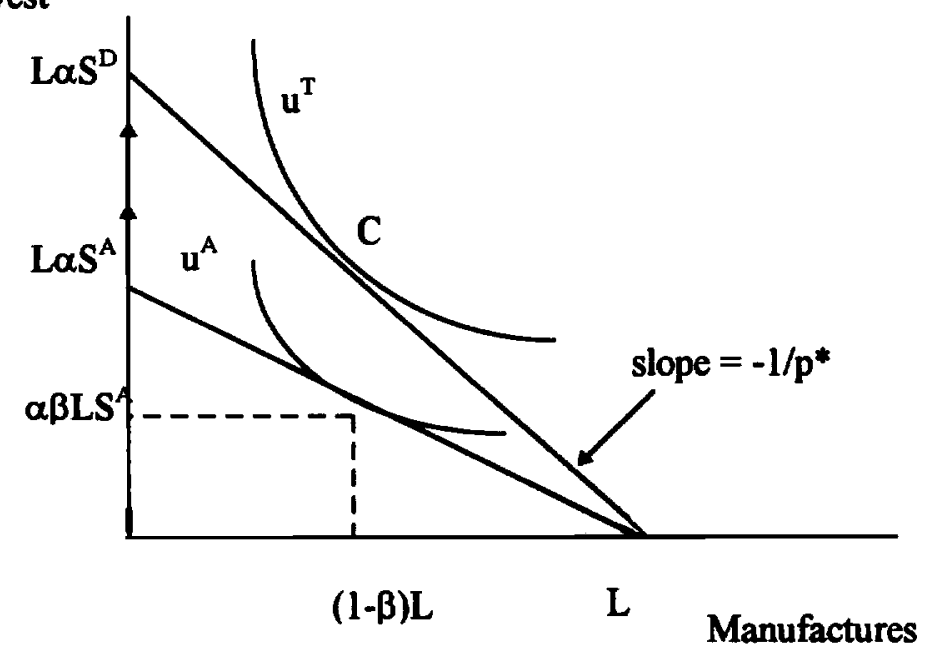

When trade opens, the economy specializes in and exports manufactures, while it imports the resource good. From Figure 4 we see that there are initial gains from trade. Because the economy's entire labor force is dedicated to manufacturing, the harvest is zero, and the resource stock grows in accordance with (2).

As the resource stock grows, the potential productivity of labor in the resource sector also grows, and the economy's production possibility frontier pivots up as shown by the arrows. Production of the resource is still zero during the transition phase and manufacturing output is constant (and equal to L). Therefore, exports of manufactures, imports of the resource good, and instantaneous utility are constant over time. This process continues until either the value of marginal product in the resource sector rises to 1 and the economy becomes diversified, or the stock grows until it reaches its carrying capacity $K$. The stock will reach $K$ if the world price of the resource good is so low that the potential wage in manufacturing remains less that 1 even at $S$ $=\mathbf{K}$. In this latter case, the economy remains specialized in steady state. 
Figure 4 illustrates the case in which the economy becomes diversified. In this case, the steady state production possibility frontier is coincident with initial trading budget line. If, on the other hand, the world price of the resource good were sufficiently low, then the budget line drawn through $\mathrm{L}$ would intersect the vertical axis at a point above LaK. In this case, the economy would remain specialized in manufactures even in steady state, and the steady state production possibility frontier would be below the budget line, sharing only the same horizontal intercept.

It can be inferred from Figure 4 that steady state utility is higher in trade than in autarky whether the steady state is diversified or specialized. In both cases the steady state consumption possibilities set under trade dominates the autarky consumption possibibilites set. It is also apparent that there are gains from trade everywhere along the transition path, hence the overall present discounted value of utility must be higher under trade than in autarky. Finally, the economy must export manufactures in steady state, even if its steady state production is diversified (and certainly if it is specialized in manufactures). The fact that even a diversified economy exports manufactures if $p^{*}<p^{A}$ follows from (20), which shows that exports of the resource good have the same sign as $\mathrm{p}^{*}-\mathrm{p}^{\mathrm{A}}$. Thus $\mathrm{p}^{*}-\mathrm{p}^{\mathrm{A}}<0$ implies that imports of the resource good are positive and the country must export manufactures.

Proposition 6: If $\mathrm{p}^{*}<\mathrm{p}^{\mathrm{A}}$, then:

i) the small country exports manufactures and imports the resource good, and

ii) steady state and present discounted utility are increased by trade.

\subsection{The Steady State Pattern of Production}


We have pointed out that specialized or diversified steady states may arise, but have not yet specificed the precise conditions that lead to one outcome or the other. Proposition 7 gives these conditions.

\section{Proposition 7:}

i) The small open economy will specialize in manufactures if (and only if)

$$
p^{*} \leq 1 / K \alpha
$$

ii) The small open economy will produce both goods if

$$
\mathrm{p}^{*}>1 / \mathrm{K} \alpha \text { and } \mathrm{L} / \mathrm{r}>\frac{1}{\alpha}\left[1-\frac{1}{\mathrm{p}^{*} \mathrm{~K} \alpha}\right]
$$

iii) The small open economy will specialize in the resource good if (and only if)

$$
\mathrm{L} / \mathrm{r} \leq \frac{1}{\alpha}\left[1-\frac{1}{\mathrm{p}^{*} \mathrm{~K} \alpha}\right]
$$

Proof: i) To specialize in manufactures, labor's value of marginal product in the resource sector must be less than 1 even at the maximum stock. Therefore, if $\mathrm{p}^{*} \alpha \mathrm{K}<1$, then the resource sector will attract no labor. Furthermore, even if $\mathrm{p}^{*} \alpha \mathrm{K}=1$, the harvest will be 0 . Inequality (26) follows immediately. ii). This follows by implication from i) and iii). We can therefore proceed directly to the proof of iii).

iii) Specialization in the resource good requires that the wage in the resource sector be greater than 1 at $S^{z}$. Therefore we require $p^{*} \alpha S^{z} \geq 1$, where $S^{z}$ is given by (25), yielding the requirement

$$
\mathrm{p}^{*} \alpha \mathrm{K}(1-\alpha \mathrm{L} / \mathrm{r}) \geq 1
$$

for specialization in the resource good. Statement iii) follows by rearranging (29). 
Proposition 7 implies the following corollary.

\section{Corollary 7.1}

If $r / L>\alpha$, then the steady-state pattern of production can be characterized as a function of world price, $\mathrm{p}^{*}$.

$$
\begin{array}{ll}
\mathrm{p}^{*} \leq 1 / \mathrm{K} \alpha & \Rightarrow \text { specialization in manufactures } \\
1 / \mathrm{K} \alpha<\mathrm{p}^{*}<\frac{1}{(1-\alpha \mathrm{L}) \mathrm{r} \alpha} & \Rightarrow \text { diversified production } \\
\mathrm{p}^{*} \geq \frac{1}{(1-\alpha \mathrm{L}) \mathrm{r} \alpha} & \Rightarrow \text { specialization in the resource good. }
\end{array}
$$

If $r / L<\alpha$, then the country cannot specialize in the resource good, regardless of the world price. $* * *$

Putting Propositions (4)-(7) together allows an interesting characterization of the consequences of trade as a function of the world price, $\mathrm{p}^{*}$.

Figure 5: Steady State Utility and the Terms of Trade

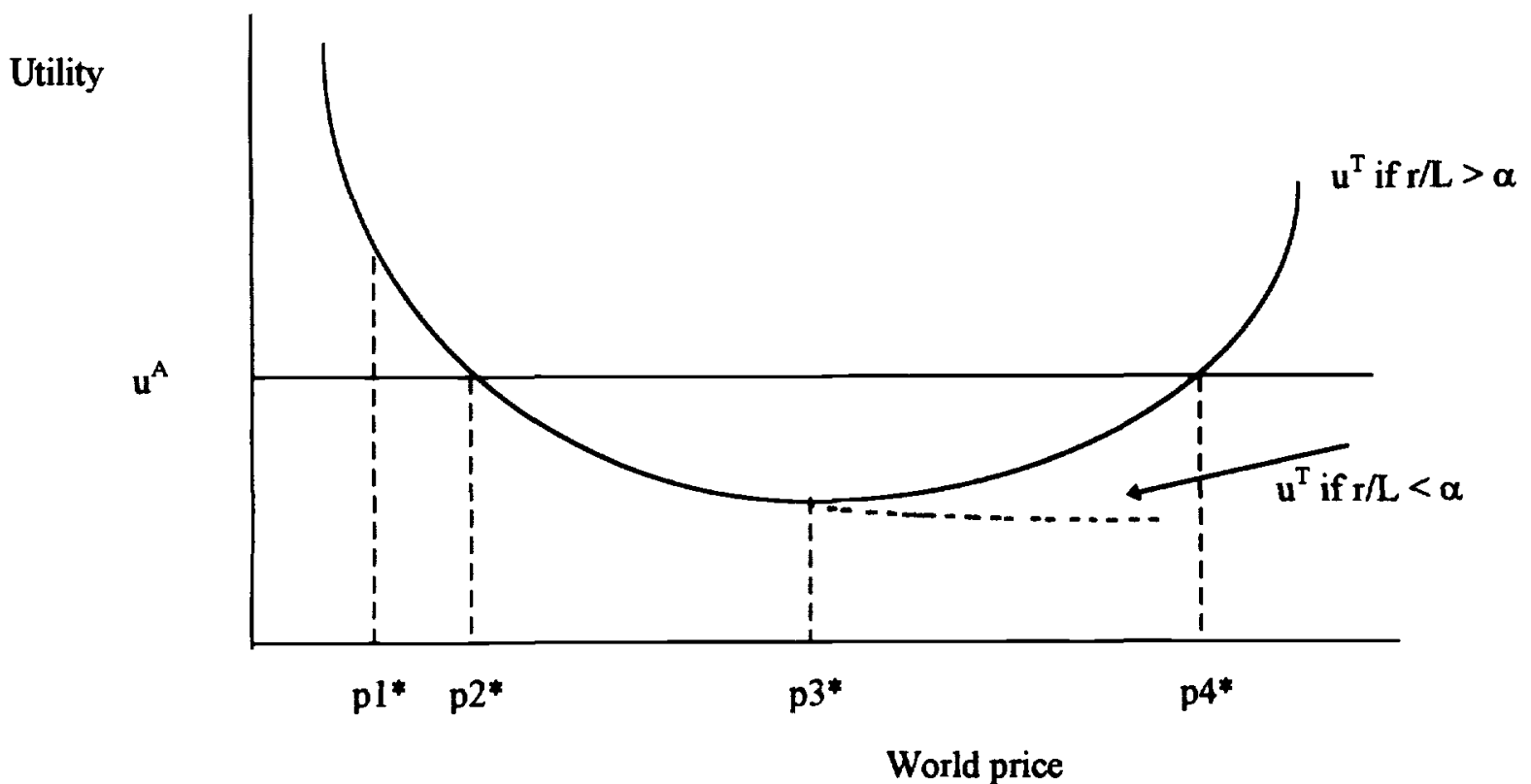


In Figure $5, u^{A}$ represents the steady state level of per capita utility under autarky. If $r / L>\alpha$, then utility under free trade, $\mathrm{u}^{\mathrm{T}}$, is U-shaped as shown by the solid line. (Ignore the dotted line for now.) Prices $\mathrm{pl}^{*}, \ldots, \mathrm{p} 4^{*}$ marked on the horizontal axis are pivotal prices. At world prices less than some price $\mathrm{pl}^{*}$, the country would specialize in manufactures. At $\mathrm{p} 1^{*}$, the domestic economy moves from specialization to diversification, but still exports manufactures. Price $p^{*} 2$ is equal to autarky price $\mathrm{p}^{\mathrm{A}}$. At all prices below $\mathrm{p}^{*}$, the domestic economy would export manufactures and would experience steady state gains from trade. At world price p2*, there would be no net trade, and the small country would be unaffected by trade.At world prices just above $\mathrm{p} 2^{*}$, the domestic economy would be an exporter of the resource good but would be diversified in production. In this range, steady-state utility under free trade would be less than in autarky.

Provided that $r / L>\alpha$, there exists a price such as $p 3^{*}$, that would be just high enough to induce the domestic economy to specialize in production of the resource good. This world price actually minimizes steady state utility for an economy that can specialize in the resource good. Beyond price $\mathrm{p}^{*}$, further increases in the world price are beneficial to the domestic economy, and there is some price, $p 4^{*}$, that yields trading steady state utility equal to autarky utility. Still higher world prices would imply steady state welfare gains relative to autarky.

If $\mathrm{r} / \mathrm{L}<\alpha$, then the country can never specialize in the resource good as the labor force is too large relative to intrinsic resource growth to be fully employed in the resource sector. Steady state utility is then continuously decreasing in the terms of trade, as shown by the dotted line. In 
this case, the stronger is the country's apparent "comparative advantage", the lower its steadystate utility.

The intuition behind these results is clear. On impact, trade always creates conventional "production" and "consumption" gains from trade. Production gains arise from shifting labor into the sector with the higher value of marginal product at world prices, raising national income. Consumption gains occur because domestic residents now face world rather than domestic prices. Over time, however, the original shift in the economy's production pattern can reduce the value of national income and the production gains from trade can eventually become production losses from trade. In essence, for an exporter of the resource good, trade magnifies the underlying open access market failure, as it induces domestic residents to attempt more intensive harvesting of an already over-exploited resource. This drives up the average cost of harvesting and lowers efficiency. If the economy remains diversified in production, this efficiency cost more than offsets conventional gains from trade.

If however, the resource good exporter specializes in production, then the value of national income falls in terms of the resource good but rises in terms of manufactures. Steady state losses from trade may occur depending on tastes and on how favourable the world terms of trade are. Unlike the case with diversified production, there are some combinations of taste parameter $\beta$ and price $\mathrm{p}^{*}$ that will allow gains from trade.

Finally, in cases where the economy exports manufactured goods, both production gains and consumption gains occur and persist. In these cases, international trade mitigates the underlying open access market failure in that it induces the country to harvest the resource stock less intensively. Note the central role of the open access market failure in this analysis. If the 
resource had enforceable property rights, this over-exploitation would not occur, and would therefore not be magnified by trade. Rents accruing to owners of the resource would rise with trade and insure aggregate gains from trade.

\section{Extensions}

We have used explicit functional forms for utility, resource growth, and the harvesting production function. Using these specific and relatively simple functional forms allows calculation of closed form solutions for variables of interest, and allows a clear understanding of the underlying economic principles at work in our analysis. We should, however, briefly consider whether the basic message of our analysis can be generalized, or whether our results are merely "artifacts" of specially chosen functional forms. In considering generalizations we focus mainly on autarky, with some discussion of the implications for trade.

Consider first the implications of more general preferences. Under the assumption of homotheticity, equation (7) becomes $H=w L f(p)$ and $M=w L(1-p f(p))$, where $f(p)$ is a positive but decreasing function of price, $\mathrm{p}$. Solving as before we find that the harvest schedule becomes $\mathbf{H}$ $=f(1 / \alpha S) L$, which is similar to (11). The slope of this harvest function is positive because $H^{\prime}(S)=$ $(\mathrm{H} / \mathrm{S}) \eta>0$, where $\eta$ is the (positive) Marshallian elasticity of demand. As before, any steady-state must satisfy the condition $H(S)=G(S)$. Suppose we assume a general concave resource growth function that satisfies $G(0)=0, G(K)=0$ for some $K>0$, and $G(S)>0$ for $S \in(0, K)$. Because the harvest function is positively sloped, we can again ensure that at least one positive steady state exists if we assume $G^{\prime}(S)>H^{\prime}(S)$ at $S=0$. This is the exact analog to the condition $r / L>\alpha \beta$ that we imposed previously. Moreover, if $\mathrm{G}(\mathrm{S})$ is linearly homogenous in $r$, then relative prices are 
again only dependent on $r / L$ even in the general homothetic utility and the generalized growth function.

Cobb-Douglas utility does have some particular features that do not generalize. Specifically, with Cobb-Douglas utility, $\eta=1$, and the harvest schedule is therefore a ray from the origin. Given the concave logistic growth curve, this implied that only one positive steady state could exist, and that it must be stable. With just general homothetic utility, the harvest function could have alternating convex and concave portions and could intersect the growth curve any number of times. Mutliple or even a continuum of steady states cannot be ruled out. Multiple solutions is a common feature of general equilibrium models with external economies (or diseconomies). In such models, the assumption that goods are gross substitutes is normally sufficient to imply uniqueness and stability of an equilibrium. That is also true here.

Even if there are multiple autarkic equilibria (and certainly if there is only one), the transitions to free trade steady states and the welfare implications of trade described in Section 4 follow much as before. Rather obviously, the diagrammatic descriptions of dynamics and gains (or losses) from trade depended only on qualitative information concerning shifts in production and consumption sets. Hence we view the central message of our analysis as relatively robust to generalizations of both tastes and biological growth.. ${ }^{12}$

\section{Concluding Remarks}

This paper examines the trade flows, production patterns and welfare outcomes for a small open economy endowed with an open access renewable resource. The pattern of production and

\footnotetext{
${ }^{12} \mathrm{We}$ can also go some way in relaxing our factor use and production function assumptions.
} 
trade follow in a very natural way from the small open economy version of comparative advantage. Specifically, whether the country exports or imports the resource good depends on whether the world price of the resource good exceeds or is less than the autarky price of the resource good in the small country. Autarky prices are in turn determined by a measure of relative resource abundance, $r / \mathrm{L}$, where $r$ is the intrinsic resource growth rate and $L$ is labor supply.

Despite the similarities to standard factor endowment models, the welfare outcomes from trade are notably different. For a significant range of cases, free trade provides lower steady-state utility than autarky. Specifically, whenever the small country exports the resource good under free trade, but has a labor force too large to allow specialization in production, steady state utility is reduced as a result of trade. Moreover, "improvements" in the terms of trade (i.e. increases in the world price of its export good) reduce steady-state welfare. If the small country can specialize in production, trade may or may not increase steady state welfare. A small country that exports manufactures must gain from trade.

There are many additional lines of research that could be pursued. We have focussed on the small open economy as a useful starting point. Arguably, this is an empirically plausible representation for various low income countries producing renewable resource products. A natural next step would be to consider a simple two-country model with endogenous world prices. Preliminary analysis of this case indicates that it does not undermine the "losses from trade" possibility, nor our pattern of trade results.

Throughout our analysis we have deliberately excluded any discussion of "optimal policy." It should be understood that the losses from trade and, for that matter, the inefficiencies arising under autarky, could be prevented by introducing an efficient resource management policy. In 
addition to simply establishing property rights, alternative first-best policies could take the form of either quantity restrictions or taxes. By assumption, however, such solutions are not possible, or at least not complete. If they were, the open access problem would not be relevant. Even if firstbest solutions cannot be undertaken, there are possible second-best approaches, such as trade restrictions. Another second best possibility would be to impose a modified "Hartwick's rule" (see Hartwick (1977)) under which an exporting country that experienced temporary gains from selling a resource good on world markets might re-invest those proceeds in an alternative asset over which property rights were more easily established. Investigating these possibilities would require extensions of our basic model, and we see considerable scope for further investigation.

The main contribution of this paper is to show that when a renewable resource is subject to open access, or something approaching it, then free trade is not likely to be the tide that raises all boats. Improved management of renewable resources may be a necessary precondition for gains from trade for many resource-dependent countries. 


\section{REFERENCES}

Bee, Ooi Jin (1987) "Depletion of the Forest Resources in the Phillipines" Field Report Series No. 18, Institute of Southeast Asian Studies

Chichilnisky, G. (1993) "Global Environment and North-South Trade", Stanford Institute for Theoretical Economics, technical report No. 31.

Clark, Colin W. (1990) Mathematical Bioeconomics: The Optimal Management of Renewable Resources (2nd. ed.) (Wiley: New York).

Copes, P. (1970) "The Backward-Bending Supply Curve of the Fishing Industry" Scottish Journal of Political Economy vol. 17, pp. 69-77.

Dasgupta, Partha and G.M. Heal (1979) "Economic Theory and Exhaustible Resources" (Cambridge University Press: Cambridge).

Gordon, H. Scott (1954) The Economic Theory of a Common Property Resource: the Fishery. Journal of Political Economy, vol. 62 (April) 124-42.

Hartwick, John (1977) "Intergenerational Equity and the Investing of Rents from Exhaustible Resources", American Economic Review, vol. 66. pp. 972-974.

Helpman. E. (1984), "Increasing Returns, Imperfect Markets, and Trade Policy" in Handbook of International Economics, Vol. I, Ch.?, ed. by Ronald W. Jones and Peter B. Kenen (NorthHolland: Amsterdam).

Kemp, M.C. and N.V. Long (1984), "The Role of Natural Resources in Trade Models" in Handbook of International Economics, Vol. I, Ch.8, ed. by Ronald W. Jones and Peter B. Kenen (North-Holland: Amsterdam).

Loayaza, Eduardo A (1992) (with collaboration from Lucian M. Sprague), "A Strategy for Fisheries Development" World Bank Discussion Paper, Fisheries Series, No. 135.

Markusen, J.R. (1976), "Production and trade from international common property resources", Canadian Journal of Economics, 9:309-319.

Mason, C.F. and S. Polasky (1994), "Entry Deterrence in the Commons", International Economic Review, vol. 35, pp. 507-526.

McRae, J. (1978), "Optimal and Competitive Use of Replenishable Natural Resources by Open Economies", Journal of International Economics, 8, 29-54. 
Munro, Gordon R. and Anthony D. Scott (1985) "The Economics of Fisheries Management", Handbook of Natural Resource and Energy Economics, vol. II, Ch. 14, ed. by A.V. Kneese and J.L. Sweeney (North-Holland: Amsterdam).

Neher, Philip (1990), Natural Resource Economics: Conservation and Exploitation (Cambridge Unviersity Press: Cambridge.)

Rauscher, Michael (1992) "Foreign Trade and Renewable Resources", Beijer Discussion Paper No. 16, Beijer International Institute of Ecological Economics, The Royal Swedish Academy of Sciences, Box 5005, S-104 05 Stockholm, Sweden.

Scott, A.D. (1955) "The Fishery: the Objectives of Sole Ownership", Journal of Political Economy, vol. 63, pp. 116-124.

Scott, A. and C. Southey (1969), "The Problem of Achieving Efficient Regulation of a Fishery" in the Economics of Fishery Management: A Symposium, ed. by A. Scott, Institute of animal resource ecology, University of British Columbia, Vancouver, B.C.

Schaefer, M.B. (1957) "Some Considerations of Population Dynamics and Economics in Relation to the Management of Marine Fisheries", Journal of the Fisheries Research Board of Canada, 14:669-681.

Tawada, M. (1982) "A note on International Trade with a renewable resource", International Economic Review, Vol. 23, No. 1, 157-163. 